\title{
Physiologic Quality and Biochemical Characters of Barley Seeds Produced Under Nitrogen Doses and Growing Environments
}

\author{
Lanes B. A. Jaques ${ }^{1}$, Ivan R. Carvalho ${ }^{1}$, Vinícius J. Szareski ${ }^{1}$, Henrique E. Rodrigues ${ }^{2}$, Ítala T. P. Dubal ${ }^{1}$, \\ Cristian Troyjack ${ }^{1}$, João R. Pimentel ${ }^{1}$, Mayara T. Mendonça ${ }^{3}$, Giordano G. Conte ${ }^{1}$, Ricardo T. Paraginski ${ }^{2}$, \\ Francisco A. Villela ${ }^{1}$, Tiago Z. Aumonde ${ }^{1} \&$ Tiago Pedó $^{1}$ \\ ${ }^{1}$ Federal University of Pelotas, Pelotas, Rio Grande do Sul, Brazil \\ ${ }^{2}$ Federal University of Pampa, São Gabriel, Rio Grande do Sul, Brazil \\ ${ }^{3}$ Federal University of Santa Maria, Santa Maria, Rio Grande do Sul, Brazil \\ Correspondence: Ivan R. Carvalho, Federal University of Pelotas, Pelotas, Rio Grande do Sul, Brazil. E-mail: \\ carvalho.irc@gmail.com
}

Received: November 4, 2018

Accepted: January 17, 2019 Online Published: July 31, 2019

doi:10.5539/jas.v11n12p65

URL: https://doi.org/10.5539/jas.v11n12p65

\begin{abstract}
Barley (Hordeum vulgare L.) is considered one of the most important cereals, such as maize, rice and wheat, due to its multiplicity of usage, as much for human consumption as for feed. The Nitrogen is one of the main nutrients that influences the quality and productivity of barley seeds because it participates in numerous metabolic routes. It is a limiting factor of the production, the lack or the excess can bring consequence to the culture. In this manner, the present study aims to evaluate the influence of different nitrogen doses on the physiologic quality and biochemical characters of brewing barley seeds produced in two growing environments. The experiment was conducted in the 2017 crop season, in a randomized block design, organized in a factorial scheme, being 2 cultivation environment $\times 2$ brewing barley cultivars $\times 4$ nitrogen doses, disposed in four replicates. The physiological quality of the seeds was evaluated by germination, first counting of germination, accelerated aging, field emergence, shoot and root length, dry mass of shoot and root of seedlings, electrical conductivity (3, 6 and 24 hours) and isoenzymes. The growing environment promotes differences in the barley seeds physiologic quality. The nitrogen fertilizing, at dose of $120 \mathrm{~kg} \mathrm{ha}^{-1}$, results in superiority in the physiologic quality of seeds. The cultivar BRS Cauê in both environments presented higher vigor. The nitrogen fertilizing alters the isoenzymatic expression of barley seedlings, creating variation in the bands intensity, at different nitrogen doses.
\end{abstract}

Keywords: Hordeum vulgare L., vigor, brewing barley, Rio Grande do Sul, Brazil

\section{Introduction}

The barley (Hordeum vulgare L.) is a cereal of the Poaceae family, from the Triticeae tribe. It was one of the first domesticated species by human, and since, it is cultivated in diverse environments (Ferreira et al., 2015). It is considered one of the most important cereals, after corn, rice and wheat (FAOSTAT, 2018). It has an usage multiplicity, for animal and human feeding.

The production occurs in various regions of the world, as in Europe, Asia and North America, including the subtropical environments as Argentina, Uruguay and southern Brazil (Caeirão et al., 2009). In the North America, the barley stands in the ration production as part of animals' diet, partially replacing the corn (Boyles et al., 2018), although, for this end, the culture has not consolidated in Brazil. In the country, it outlooks in the brewing industry, where about $75 \%$ of the production is destined to this end (Demari et al., 2012; Szareski et al., 2017).

The production of barley grains designed to malt must present quality patterns similar to the required for seeds. However, if the barley grains do not follow the fixed limits as stated by the ordinance $n^{\circ} 691$ of November 1996 from the Ministry of Agriculture, Livestock and Supply (MAPA), it will be considered under the standard, and not being destined to malt fabrication for brewing (MAPA, 1996).

In order to elevate the performance and physical quality of seeds is fundamental to consider a set of factors, among them the soil structure, genotype adaptation, good management practices, sowing and harvesting at 
correct moment (Silva et al., 2005). Among the management practices, the nitrogenous fertilizing is a key factor, and it has direct influence in the production and seeds quality.

The nitrogen assists in innumerous transformations in the soil-plant system, entailing the plant and seed composition. It is the main nutrient required by grasses, in order to increase the yield (Souza et al., 2006; Szareski et al., 2018), being indispensable, to many metabolic routes (Sangoi et al., 2008).

Because of its importance to seeds yield, the nitrogen, if mismanaged, can bring unsatisfactory effects in yield and quality of grains and seeds (Meneghin et al., 2008). The amount of nitrogen that must be applied in the barley culture, at the Southern Brazil, is based in the organic matter content, harvesting expectation and culture history (SBCS, 2016). Although, many times the recommended fertilizing do not correspond to the culture real necessity, once the organic residue decomposition and nitrogen liberation depends on several factors linked to intrinsic characteristics of the growing environment (Szareski et al., 2016).

By natural processes, part of the nitrogen fertilizing is lost, and it reflects in its efficiency reduction (Shen et al., 2010). If these losses are not replaced and the nitrogen demand by the vegetal is not enough, the same will not express its productive and physiologic potential, what can cause low quality and reduction in the seeds productivity. In this manner, the present work aims to evaluate the influence of different nitrogen doses on the physiologic quality and chemical characters of barley seeds produced in two growing environments.

\section{Material and Methods}

\subsection{Area of Study and Sampling}

The study was realized in the crop year of 2017, in two growing environments, being located in Alegrete-RS, at the experimental field of the Farroupilha Federal Institute, in the coordinates with latitude $29^{\circ} 47^{\prime} 01.63^{\prime \prime}$ Sul and

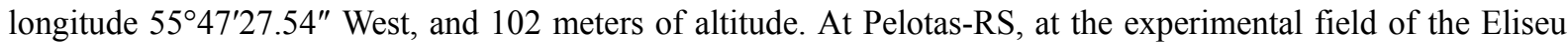
Maciel College of Agriculture, with coordinates of 52 $21^{\prime} 24^{\prime \prime}$ West and 31 $52^{\prime} 00^{\prime \prime}$ Sul, and 13.4 meters of altitude.

The climate of the municipality of Alegrete-RS is Cfa type, subtropical warm temperate according to Köppen-Geiger classification, with average winter temperature of $14.2{ }^{\circ} \mathrm{C}$ and $35.8{ }^{\circ} \mathrm{C}$ in the summer, with annual precipitation of $1500 \mathrm{~mm}$. The soil is a Paleudal $\mathrm{f}^{14}$. At Pelotas-RS, the climate is humid subtropical, Cfa type (Vieira et al., 1999), with annual rainfall of $1280 \mathrm{~mm}$ (Tunes et al., 2010). The soil is classified as Solodic Planosol (Embrapa, 2013).

The meteorological registers referent to the minimum and maximum air temperature $\left({ }^{\circ} \mathrm{C}\right)$, air relative humidity (\%), incident solar radiation ( $\mathrm{cal} \mathrm{cm}^{2} \mathrm{~d}^{-1}$ ), and rainfall accumulation $(\mathrm{mm})$, during the experiment conduction are presented at the Figure 4, for both growing environments.

For the experiment implementation, it was realized the soil sampling, in the areas with $0-20 \mathrm{~cm}$ of soil depth, according to (Raij, 1983). The fertilizing of (NPK) and nitrogen were realized based on the soil analysis. The nitrogen fertilizing was constituted of four nitrogen doses, being 80,120, 160 and $200 \mathrm{~kg} \mathrm{ha}^{-1}$. The application was realized in the stage of full tillering.

\subsection{Experimental Design}

The experimental design used was randomized blocs organized in factorial scheme, being $2 \times 2 \times 4$ (growing environments $) \times($ barley cultivars $) \times($ nitrogen doses $)$, disposed in four replicates. Were used two cultivars, being BRS Brau and BRS Cauê. When achieving the physiologic maturity and $20 \%$ of humidity, the seeds were harvested and manually trashed. Afterwards, they were sent to the Laboratory of Seeds Analysis of the Plants Science Department, of the Graduate Program in Seeds Science and Technology, at the Eliseu Maciel College of Agriculture, Campus Capão do Leão-RS, Federal University of Pelotas.

The seeds were submitted to drying at stationary dryer until obtaining $13 \%$ humidity. The barley presents seed dormancy, in this manner it was realized the dormancy breaking with $10{ }^{\circ} \mathrm{C}$ during seven days, as described by the Seeds Analysis Rules (MARA, 2009).

\subsection{Characters Studied}

In order to evaluate the influence of nitrogen doses, on the physiologic quality of barley produced in two growing environments, it was realized the following analysis: germination $(\mathrm{G})$, first germination counting (PCG), accelerated aging (EA), field emergence (EM), seedlings shoot and root length (CPA, CR), shoot and root dry matter of seedlings (WPA, WR), electric conductivity $(\mathrm{CH})$ with readings of 3, 6 and 24 hours and isoenzimatic expression through esterase (E), acid phosphatase (FAC), glutamate oxaloacetate transaminase (GOT) and super-oxidose dismulase (SOD). 
Germination $(G)$ : the germination test was conducted in four experimental units with four subsamples of 50 seeds, for each treatment. The seeds were disposed in germitest paper, soaked in distillated water with quantity of 2.5 times the mass of the dry substrate, looking for the adequate humidity. The rolls were conditioned in germinator with $20{ }^{\circ} \mathrm{C}$ of temperature. The counting was realized in the seventh day after sowing, the results were expressed in normal seedlings percentage (MARA, 2009).

First Germination Counting (PCG): realized parallel to the germination test, it was evaluated the percentage of normal seedlings, obtained by three experimental units with four subsamples of 50 seeds, for each treatment. The counting was realized with four days after the sowing. The results were expressed in normal seedlings (MARA, 2009).

Accelerated Aging (EA): the test was conducted thru the use of gerbox boxes, with lamina of $40 \mathrm{~mL}$ of saturated saline solution, with 40 grams of $\mathrm{NaCl}$ in $100 \mathrm{~mL}$ of water as described by Jianhua and Mcdonald (1996). The seeds were disposed on a screen positioned above the solution lamina and maintained in $41^{\circ} \mathrm{C}$ kiln, for 72 hours. After this period, it was conducted the germination test, according to the criteria established in the Seeds Analysis Rules (MARA, 2009).

Field Emergence (EM): evaluated from the sowing of four experimental units by treatments, sowed in plots with soil. The seedlings counting of normal seedlings was realized at 21 days after sowing, being the results expressed in percentage (Szareski et al., 2018).

Length of Shoot (CPA) and Root (CR) of Seedlings: it was used four experimental units with four subsamples of 30 seeds per treatment. It was randomly valued the length of 10 normal seedlings. The seeds were disposed in the superior third of the germitest paper, and then directed to a germinator with $20{ }^{\circ} \mathrm{C}$ temperature for seven days After the end of the seven days, it was calculated the length of the shoot and root of seedlings with the assistance of a graduated ruler (Nakagawa et al., 1999).

Dry Matter of Shoot (MPA) and Root (MR) of Seedlings: it was realized analogously with the seedling length. It was collected 10 seedlings per treatment, separating the shoot from the root. Each part was conditioned on kraft paper envelope and submitted to drying at kiln with forced air circulation, with temperature of $70 \pm 2{ }^{\circ} \mathrm{C}$, until reaching constant mass. The results were expressed in grams per seedling $\left(\mathrm{g}\right.$ seedling ${ }^{-1}$ ), according to Nakagawa (Szareski et al., 2018).

Electric Conductivity $(\mathrm{CH})$ : the evaluation was conducted from four experimental units with four subsamples of 50 seeds, weighted in precision scale and disposed in a polypropylene container with $75 \mathrm{~mL}$ of deionized water, maintained in Biochemical Oxigen Demand (BOD). For the soaking, it was maintained with temperature of 20 ${ }^{\circ} \mathrm{C}$. The electrolytes lixiviation was measured by a conductivity meter, at three, six and twenty four hours. The results were expressed in $\mu \mathrm{S} \mathrm{cm}^{-1} \mathrm{~g}^{-1}$ of seeds (Viana et al., 2010).

Isoenzimatic Expression (EI): determined from four experimental units and four subsamples of each treatment. It were randomly collected 10 seedlings for the vegetal extraction, and macerated in porcelain mortar.

The expression of the esterase isoenzyme (ES), acid phosphatase (FAC), glutamate oxaloacetate transaminase (GOT) and super-oxidose dismulase (SOD), was determined using the vertical electrophorese system in polyacrylamide gel. From each macerated treatment, it were collected $200 \mathrm{mg}$ of vegetal extract, and were conditioned in tubes of Heppendorf, added by extracting solution (buffer gel- $0.15 \%$ of 2-mercaptoethanol) at the proportion 1:3 (p/v). The vertical electrophorese system was set in $7 \%$ polyacrylamide gels, with $20 \mu \mathrm{L}$ of vegetal material, in orifices created with the assistance of an acrylic comb.

The gels were conditioned in electrophoretic cubes with movement, maintained in environment temperature for two hours, until the front run, formed by the bromophenol blue, achieved nine centimeters from the application point. The isoenzymatic patterns were realized by the buffer system described by Scandalios (Scandalias, 1969). The results interpretation was based in the visual analysis of the electrophorese gels, considering the presence or absence, and the quantification of the bands realized from the Gel-Pro Analyzer 3.1 software.

\subsection{Statistical Analysis}

The data were submitted to variance analysis aiming to verify the model presumptions, normality and homogeneity of variances. Afterwards it was executed the identification of the growing environment $\times$ barley genotypes $\times$ nitrogen doses interaction to all the measured variables, with $5 \%$ by $\mathrm{F}$ test.

The significant interactions were derived to simple effects for the qualitative variation factor (growing environment $\times$ barley cultivars), for the quantitative factor (nitrogen doses) it was proceeded the linear regression and tested the polynomial higher significant degree, thru $t$ test at $5 \%$ probability, for each level of the 
qualitative variance factors. The non-significant interactions were separately derived to principal effects for each factor.

\section{Results and Discussion}

The variance analysis revealed significance, at $5 \%$ of probability, to the interactions growing environment $\mathrm{x}$ barley cultivars $\times$ nitrogen doses thru the variables germination $(\mathrm{G})$, first germination counting (PCG), accelerated aging (EA), field emergence (EM), electric conductivity $(3,6$ and 24 hours $-\mathrm{CH})$, root length (CR) and shoot dry matter. Also, found significant interaction between growing environments $\times$ nitrogen doses to the variable seedlings shoot length (CPA), and significant interaction to barley cultivars $\times$ nitrogen doses in relation to shoot length (CPA) (Table 1). Significant effects to the variable seedlings dry matter was verified for barley cultivars.

Table 1. Summary of the variance analysis to the variables referent to barley physiologic quality, produced in growing environments (Alegrete-RS and Pelotas-RS), with barley cultivars (BRS Brauand BRS Cauê) and nitrogen doses ( $80 \mathrm{~kg} \mathrm{ha}^{-1}, 120 \mathrm{~kg} \mathrm{ha}^{-1}, 160 \mathrm{~kg} \mathrm{ha}^{-1}$ and $\left.200 \mathrm{~kg} \mathrm{ha}^{-1}\right)$, at growing season of 2017

\begin{tabular}{|c|c|c|c|c|c|c|c|c|c|c|c|c|}
\hline \multirow{2}{*}{ V.F. } & \multirow{2}{*}{ GL } & \multicolumn{11}{|c|}{ Mean Squares } \\
\hline & & G & PCG & EA & EM & CPA & CR & MPA & MR & $\mathrm{CH} 3 \mathrm{H}$ & $\mathrm{CH} 6 \mathrm{H}$ & $\mathrm{CH} 24 \mathrm{H}$ \\
\hline Growing environment (A) & 1 & $607.98^{*}$ & $364.61 *$ & $781.05^{*}$ & $65.35^{*}$ & $7.92 *$ & $1.32^{\mathrm{ns}}$ & $0.00014^{\mathrm{ns}}$ & $0.00024^{\mathrm{ns}}$ & $512.10^{*}$ & $721.96^{*}$ & $14667.6^{*}$ \\
\hline Barley cultivar (C) & 1 & $1183.35^{*}$ & $1280.5^{*}$ & $3088.7^{*}$ & $757.96^{*}$ & $5.01^{*}$ & $300.63^{*}$ & $0.00004^{\text {ns }}$ & $0.00030^{*}$ & $79.63^{\mathrm{ns}}$ & $201.67^{\text {ns }}$ & $16423.7^{*}$ \\
\hline $\mathrm{A} \times \mathrm{C}$ & 1 & $625.87^{*}$ & $634.74 *$ & $45.58^{\text {ns }}$ & $33.58^{\mathrm{ns}}$ & $29.08^{*}$ & $17.82 *$ & $0.00005^{\mathrm{ns}}$ & $0.00005^{\mathrm{ns}}$ & $341.11 *$ & $210.84^{\text {ns }}$ & $579.14 *$ \\
\hline Nitrogen doses (D) & 3 & $31.44^{\mathrm{ns}}$ & $37.90^{\mathrm{ns}}$ & $352.93 *$ & $10.35^{\text {ns }}$ & $0.91^{\mathrm{ns}}$ & $17.73^{*}$ & $0.00006^{\text {ns }}$ & $0.00001^{\text {ns }}$ & $465.26^{*}$ & $548.06^{*}$ & $1479.5^{*}$ \\
\hline$A \times D$ & 3 & $19.00^{\mathrm{ns}}$ & $20.26^{\mathrm{ns}}$ & $242.34 *$ & $131.03 *$ & $2.97 *$ & $17.36^{*}$ & $0.00041^{*}$ & $0.00013^{\text {ns }}$ & $160.71^{*}$ & $242.87^{*}$ & $435.48^{*}$ \\
\hline $\mathrm{C} \times \mathrm{D}$ & 3 & $23.48^{\mathrm{ns}}$ & $31.72^{\mathrm{ns}}$ & $193.27^{\text {ns }}$ & $27.39^{\text {ns }}$ & $5.10^{*}$ & $17.52 *$ & $0.00031^{*}$ & $0.00003^{\text {ns }}$ & $267.45^{*}$ & $286.79 *$ & $874.57^{*}$ \\
\hline $\mathrm{A} \times \mathrm{C} \times \mathrm{D}$ & 3 & $215.84 *$ & $249.97 *$ & $441.61^{*}$ & $88.41^{*}$ & $1.23^{\mathrm{ns}}$ & $39.56^{*}$ & $0.00030^{*}$ & $0.000001^{\mathrm{ns}}$ & $236.44 *$ & $245.26^{*}$ & $860.65^{*}$ \\
\hline Bloco & 3 & $25.12^{\mathrm{ns}}$ & $41.31^{\mathrm{ns}}$ & $20.67^{\mathrm{ns}}$ & $27.02^{\mathrm{ns}}$ & $6.27 *$ & $3.72^{\mathrm{ns}}$ & $0.00006^{\mathrm{ns}}$ & $0.000005^{\text {ns }}$ & $97.40^{*}$ & $315.06^{*}$ & $486.18^{*}$ \\
\hline CV (\%) & - & 5.54 & 5.90 & 10.73 & 8.80 & 20.42 & 21.38 & 16.41 & 16.13 & 18.04 & 16.91 & 14.68 \\
\hline $\mathrm{R}^{2}$ & & 0.69 & 0.62 & 0.80 & 0.92 & 0.52 & 0.75 & 0.60 & 0.62 & 0.88 & 0.93 & 0.88 \\
\hline
\end{tabular}

Note. ${ }^{*}$ and ${ }^{\text {ns }}$, significant at $5 \%$ of probability and non-significant, respectively.

VF: Variation Factor; G: Germination (\%); PCG: First Counting of Germination (\%); EA: Accelerated Aging (\%); EM: Field Emergence (\%); CPA: Shoot Length of Seedlings (cm); CR: Root Length of Seedlings (cm); MPA: Shoot Dry Matter of Seedlings (g); MR: Root Dry Matter of Seedlings (g); CH: Electric Conductivity $\left(\mu \mathrm{S} \mathrm{cm}^{-1} \mathrm{~g}^{-1}\right.$; 3,6 and 24 hours).

Analyzing the variation factors, it is verified that the growing environments and barley cultivars present higher mean square, it results in higher vulnerability to the attributes from the physiologic quality of seeds. The genetic constitution of cultivars differentiate on its answer to the environment, to the growth habit, cycle, seeds yield, resistance and/or tolerance to disease and pests (Szareski et al., 2016).

For the germination variable $(\mathrm{G})$, it was verified differences due to nitrogen doses towards barley cultivars. The Alegrete-RS, revealed that the cultivar BRS Cauê demonstrated higher germinating performance in relation to BRS Brau. Both cultivars adjusted itself to the linear model, where BRS Brau presented a crescent increase until $200 \mathrm{~kg} \mathrm{ha}^{-1}$ nitrogen dose, resulting in $94 \%$ of normal seedlings. The BRS Cauê express decreasing behavior, due to the effect of nitrogen doses, with $94 \%$ of germinated seedlings.

The Pelotas environment highlighted the cultivar BRS Cauê, which adjusted to the crescent linear model, due to the increase of nitrogen doses, resulting in $95 \%$ of germination at $200 \mathrm{~kg} \mathrm{ha}^{-1}$ nitrogen dose. The BRS Brau cultivar adjusted itself to the quadratic polynomial model, and its lower efficiency point was revealed at $143 \mathrm{~kg}$ $\mathrm{ha}^{-1}$ nitrogen dose, presenting $84 \%$ of normal seedlings.

The interaction derivation, among growth environments $\times$ barley cultivars $\times$ nitrogen doses, demonstrated that the cultivar BRS Brau obtained higher germinating potential at Alegrete-RS. These results statistically differ in doses of $120 \mathrm{~kg} \mathrm{ha}^{-1}, 160 \mathrm{~kg} \mathrm{ha}^{-1}$ and $200 \mathrm{~kg} \mathrm{ha}^{-1}$ when compared to Pelotas-RS. The $120 \mathrm{~kg} \mathrm{ha}^{-1}$ nitrogen dose in Alegrete-RS resulted in $95 \%$ of normal seedlings, while in Pelotas-RS evidenced $83 \%$ of normal seedlings. The cultivar BRS Cauê was superior in Pelotas-RS, although, the doses fos $120 \mathrm{~kg} \mathrm{ha}^{-1}, 160 \mathrm{~kg} \mathrm{ha}^{-1}$ and $200 \mathrm{~kg} \mathrm{ha}^{-1}$ 
do not differ, only the dose of $80 \mathrm{~kg} \mathrm{ha}^{-1}$ demonstrated difference, with a $95 \%$ germination at the Alegrete-RS environment.

The Alegrete-RS environment presented higher germinated seeds percentual. It can be associated with answers to nitrogen doses and climate conditions. Nitrogen doses superior to $160 \mathrm{~kg} \mathrm{ha}^{-1}$ are not favorable to germination increase. For the cultivar BRS Brau, the best answer was obtained using the dose of $120 \mathrm{~kg} \mathrm{ha}^{-1}$ of nitrogen, and for the cultivar BRS Cauê the best answer was achieved with dose of $80 \mathrm{~kg} \mathrm{ha}^{-1}$ of nitrogen. The increase of nitrogen doses do not follow a tendency similar to germination percentage increase on produced seeds.

For Alegrete-RS, the environmental conditions demonstrated lower air temperature in relation to Pelotas-RS. During the experiment conduction, the maximum air temperatures oscillated between $13{ }^{\circ} \mathrm{C}$ and $23{ }^{\circ} \mathrm{C}$ and the minimum temperatures between $11^{\circ} \mathrm{C}$ and $21^{\circ} \mathrm{C}$. The incident radiation during the experiment was superior in Alegrete-RS, although it was not excessive, at a point of harming the seeds germination.

In relation to the first germination counting (PCG), for the Alegrete-RS environment, the cultivar BRS Cauê had the best performance for the nitrogen doses, adjusting to the decreasing linear model, due to the increase in the dose of nitrogen, corresponding to $94 \%$ of normal seedlings. The cultivar BRS Brau adjusted to the crescent linear tendency, with $94 \%$ of normal seedlings.

At the Pelotas-RS environment, the cultivar BRS Cauê expressed the higher magnitudes. In relation to the first germination counting, the BRS Cauê adjusted to the crescent linear model, because of the increase of the nitrogen dose, achieving $95 \%$ vigor. The lowest nitrogen dose was $80 \mathrm{~kg} \mathrm{ha}^{-1}$, resulting in seeds with inferior germination, which means, $91 \%$ of normal seedlings. The cultivar BRS Brau adjusted to the quadratic tendency with point of minimum efficiency thru $140 \mathrm{~kg} \mathrm{ha}^{-1}$ nitrogen does, and $83 \%$ of normal seedlings.

There was significant difference among barley cultivars produced at Alegrete-RS environment in relation to Pelotas-RS. The BRS Brau cultivar demonstrated better performance at Alegrete-RS, in the nitrogen dose of 120 $\mathrm{kg} \mathrm{ha}^{-1}$, achieving $94 \%$ of normal seedlings, while the same dose, at Pelotas-RS, was inferior to $81 \%$. The cultivar BRS Cauê had the best performance in Pelotas-RS, with the dose of $120 \mathrm{~kg} \mathrm{ha}^{-1}$ of nitrogen. The increase in doses to 160 and $200 \mathrm{~kg} \mathrm{ha}^{-1}$ of nitrogen did not favored the increase of normal seedlings at the first counting of the germination test.

The first germination counting analyzing two growing environments, the cultivar BRS Brau adapted better at Alegrete-RS, considering seeds vigor, and for Pelotas-RS, the BRS Cauê had a better behavior.

The vigor evaluation by the accelerated aging test (EA) evidenced that, at the Alegrete-RS environment, the cultivar BRS Cauê demonstrated more vigorous, statically differing in the nitrogen dose of $80 \mathrm{~kg} \mathrm{ha}^{-1}$ and $200 \mathrm{~kg}$ $\mathrm{ha}^{-1}$ in the BRS Brau. The accelerated aging revealed a quadratic model for the cultivar BRS Brau, with maximum efficiency to the nitrogen dose of $140 \mathrm{~kg} \mathrm{ha}^{-1}$, and $86 \%$ of normal seedlings. The BRS Cauê adjusted to a linear and crescent tendency due to the increase of nitrogen doses, resulting in $88 \%$ of germination.

Table 2. Derivation of the interaction between growing environment (Alegrete-RS and Pelotas-RS) $\times$ barley cultivars (BRS Brau and BRS Cauê) $\times$ nitrogen doses

\begin{tabular}{|c|c|c|c|c|}
\hline \multirow{3}{*}{ Nitrogen doses $\left(\mathrm{kg} \mathrm{ha}^{-1}\right)$} & \multicolumn{4}{|c|}{ Accelerated aging } \\
\hline & \multicolumn{2}{|c|}{ Alegrete-RS } & \multicolumn{2}{|c|}{ Pelotas-RS } \\
\hline & BRS Brau & BRS Cauê & BRS Brau & BRS Cauê \\
\hline 80 & $78 \mathrm{~B} \alpha$ & $88 \mathrm{~A} \alpha$ & $75 \mathrm{~A} \alpha$ & $72 \mathrm{~A} \beta$ \\
\hline 120 & $85 \mathrm{~A} \alpha$ & $84 \mathrm{~A} \alpha$ & $75 \mathrm{~B} \beta$ & $91 \mathrm{~A} \alpha$ \\
\hline 160 & $84 \mathrm{~A} \alpha$ & $88 \mathrm{~A} \alpha$ & $78 \mathrm{~B} \alpha$ & $85 \mathrm{~A} \alpha$ \\
\hline 200 & $76 \mathrm{~B} \alpha$ & $88 \mathrm{~A} \alpha$ & $76 \mathrm{~B} \alpha$ & $89 \mathrm{~A} \alpha$ \\
\hline $\mathrm{CV}(\%)$ & 10.73 & & & \\
\hline \multirow{3}{*}{ Nitrogen doses $\left(\mathrm{kg} \mathrm{ha}^{-1}\right)$} & \multicolumn{4}{|c|}{ Field Emergence } \\
\hline & \multicolumn{2}{|c|}{ Alegrete-RS } & \multicolumn{2}{|c|}{ Pelotas-RS } \\
\hline & BRS Brau & BRS Cauê & BRS Brau & BRS Cauê \\
\hline 80 & $76 \mathrm{~B} \alpha$ & $87 \mathrm{~A} \alpha$ & $72 \mathrm{~B} \alpha$ & $80 \mathrm{~A} \beta$ \\
\hline 120 & $78 \mathrm{~A} \alpha$ & $78 \mathrm{~A} \beta$ & $73 \mathrm{~B} \alpha$ & $90 \mathrm{~A} \alpha$ \\
\hline 160 & $76 \mathrm{~A} \alpha$ & $78 \mathrm{~A} \alpha$ & $75 \mathrm{~B} \alpha$ & $82 \mathrm{~A} \alpha$ \\
\hline 200 & $70 \mathrm{~B} \beta$ & $79 \mathrm{~A} \beta$ & $82 \mathrm{~A} \alpha$ & $84 \mathrm{~A} \alpha$ \\
\hline $\mathrm{CV}(\%)$ & 8.80 & & & \\
\hline
\end{tabular}


Note. *Means followed by the same uppercase letter in the line (barley cultivars), and in the same Greek letter in the line (growing environments) do not statistically differ on Tukey test with $5 \%$ of probability.

Analyzing the vigor for Pelotas-RS, the cultivar BRS Cauê obtained higher magnitude for normal seedlings with nitrogen dose of $120 \mathrm{~kg} \mathrm{ha}^{-1}$. It was observed that the nitrogen dose increase to $200 \mathrm{~kg} \mathrm{ha}^{-1}$ minimized the physiological potential in this test. The cultivar BRS Brau presented a crescent linear tendency with $76 \%$ of normal seedlings. It is observed that the Alegrete-RS environment presented better results for both studied cultivars, when seeds were exposed to adverse conditions, obtaining higher vigor and physiologic quality.

The increase in nitrogen doses above $120 \mathrm{~kg} \mathrm{ha}^{-1}$ did not increased germination, where the cultivar BRS Brau, at Alegrete-RS growing environment, differed from cultivar BRS Cauê. The nitrogen dose of $120 \mathrm{~kg} \mathrm{ha}^{-1}$ revealed $85 \%$ germination and superior doses caused $76 \%$ reduction of normal seedlings.

The field emergence (EM) presented, for environment Alegrete-RS, superiority to the cultivar BRS Cauê in all used nitrogen doses in relation to the BRS Brau cultivar. It adjusted to the quadratic model with minimum efficiency point at the dose of $162 \mathrm{~kg} \mathrm{ha}^{-1}$, with $78 \%$ of germination. The cultivar BRS Brau adjusted to the quadratic model, with maximum efficiency at the nitrogen dose of $121 \mathrm{~kg} \mathrm{ha}^{-1}$, presenting $78 \%$ of germinated seeds. The answer of the cultivar BRS Cauê to the nitrogen dose demonstrated higher vigor at $80 \mathrm{~kg} \mathrm{ha}^{-1}$ of nitrogen, showing $87 \%$ germination, while to the cultivar BRS Brau, the better expression was obtained with dose of $120 \mathrm{~kg} \mathrm{ha}^{-1}$.

By analyzing the growing environment of Pelotas-RS, it is observed that the cultivar BRS Caue presented higher vigor, adjusting to a crescent linear model with $84 \%$ of seedlings in the higher dose. The cultivar BRS Brau obtained lower performance, adjusting to a crescent linear tendency, with $76 \%$ of normal seedlings at maximum dose. For this environment, the dose of $120 \mathrm{~kg} \mathrm{ha}^{-1}$ brought increment to the germination potential thru the cultivar BRS Cauê, reflecting in $90 \%$ of seeds germination.

The unfolding demonstrates that the environment Pelotas-RS obtained higher vigor by the field emergency test. For the BRS Cauê cultivar, the best performance was verified in the 120 and $200 \mathrm{~kg} \mathrm{ha}^{-1}$ nitrogen dose. For the cultivar BRS Brau, the best performance was verified with the nitrogen dose of $200 \mathrm{~kg} \mathrm{ha}^{-1}$.

The variable seedling shoot length (CPA) revealed to the interaction among growing environments $\times$ nitrogen doses that, as much for Alegrete-RS as for Pelotas-RS, both adjusted to a decreasing linear tendency due to the increase in nitrogen dose. The derivation of the interaction growing environment $\times$ nitrogen doses, allowed the verification that Alegrete-RS presented higher seedlings length, although did not differed Pelotas-RS at the doses 80,120 and $200 \mathrm{~kg} \mathrm{ha}^{-1}$, with difference only for the dose $160 \mathrm{~kg} \mathrm{ha}^{-1}$ (Table 3). However, the highest seedlings shoot length were obtained in doses of 80 and $120 \mathrm{~kg} \mathrm{ha}^{-1}$, where the dose increment did not favored this character in both growing environments.

Table 3. Derivation of the interation between barley cultivars (BRS Brau and BRS Cauê) $\times$ nitrogen dose, for the variable shoot length of seedlings (CPA)

\begin{tabular}{llc}
\hline \multirow{2}{*}{ Nitrogen doses $\left(\mathrm{kg} \mathrm{ha}^{-1}\right)$} & \multicolumn{2}{c}{ Growing environments } \\
\cline { 2 - 3 } & Alegrete-RS & Pelotas-RS \\
\hline 80 & $5.32 \mathrm{~A}$ & $5.00 \mathrm{~A}$ \\
120 & $4.89 \mathrm{~A}$ & $5.06 \mathrm{~A}$ \\
160 & $5.32 \mathrm{~A}$ & $4.83 \mathrm{~B}$ \\
200 & $5.15 \mathrm{~A}$ & $4.88 \mathrm{~A}$ \\
\hline $\mathrm{CV}(\%)$ & 20.42 & \\
\hline Nitrogen doses & & Barley cultivars \\
$\left(\mathrm{kg} \mathrm{ha}^{-1}\right)$ & BRS Brau & BRS Cauê \\
\hline 80 & $5.26 \mathrm{~A}$ & $5.06 \mathrm{~A}$ \\
120 & $5.31 \mathrm{~A}$ & $4.63 \mathrm{~B}$ \\
160 & $4.99 \mathrm{~A}$ & $5.17 \mathrm{~A}$ \\
200 & $5.03 \mathrm{~A}$ & $5.00 \mathrm{~A}$ \\
\hline $\mathrm{CV}(\%)$ & 20.42 & \\
\hline
\end{tabular}

Note. *Means followed by the same uppercase letter in the line do not statistically differ on Tukey test with $5 \%$ of probability. 
For the seedling root length (CR), revealed that for the Alegrete-RS environment, both cultivars presented linear tendency. The cultivar BRS Brau adjusted to a decreasing linear tendency with the increase of the nitrogen dose, what resulted in $7.09 \mathrm{~cm}$ in the higher used dose. For the BRS Cauê, the adjust presented a crescent tendency, thru the nitrogen dose, reflecting in $9.89 \mathrm{~cm}$ at the maximum dose.

The environment of Pelotas-RS pointed that the cultivar BRS Brau adjusted to a quadratic tendency, with minimum efficiency value with the nitrogen dose of $143 \mathrm{~kg} \mathrm{ha}^{-1}$, resulting in $6.20 \mathrm{~cm}$ of root length. For the BRS Cauê, this variable adjusted to a decreasing linear tendency, with $8.81 \mathrm{~cm}$ at the maximum used dose.

The variable seedling root length (Table 4) evidenced, for the cultivar BRS Brau, better performance in Alegrete-RS, although statistically differed from Pelotas-RS with the nitrogen dose of $120 \mathrm{~kg} \mathrm{ha}^{-1}$. When analyzing the cultivar BRS Brau, it was verified that both growing environments the dose of $80 \mathrm{~kg} \mathrm{ha}^{-1}$ demonstrated higher root length. The cultivar BRS Caue resulted in higher magnitude for this character at Pelotas-RS, thru the nitrogen dose of $120 \mathrm{~kg} \mathrm{ha}^{-1}$ (Table 4). For this variable, it is evident that the increase in nitrogen dose above $120 \mathrm{~kg} \mathrm{ha}^{-1}$, caused reduction in the seedling radicular system.

For the shoot dry matter of seedlings (MPA) at the Alegrete-RS environment, the cultivars showed a crescent linear tendency due to the increase in the nitrogen dose, where both barley cultivars resulted in 0.05 grams of dry matter in the nitrogen dose of $200 \mathrm{~kg} \mathrm{ha}^{-1}$.

The cultivars showed, for the environment Pelotas, differential answers thru the increment of the nitrogen dose. The cultivar BRS Brau, adjusted to a decreasing linear tendency, with superiority to the nitrogen dose of $200 \mathrm{~kg}$ $\mathrm{ha}^{-1}$ and accumulation of 0,051 grams. The cultivar BRS Cauê demonstrated crescent linear tendency, as the nitrogen dose increased, resulting in mass of 0.0054 grams, respectively.

For the variable shoot dry matter of seedlings, the cultivar BRS Brau presented higher mass at Pelotas-RS, showing statistic difference in the dose of $80 \mathrm{~kg} \mathrm{ha}^{-1}$ (Table 4). The cultivar BRS Cauê at Pelotas-RS, was superior, thru the doses of $80 \mathrm{~kg} \mathrm{ha}^{-1}, 120 \mathrm{~kg} \mathrm{ha}^{-1}$ and $200 \mathrm{~kg} \mathrm{ha}^{-1}$.

Table 4. Derivation of the interaction growing environments (Alegrete-RS and Pelotas-RS) $\times$ barley cultivars (BRS Brau and BRS Cauê) $\times$ nitrogen doses

\begin{tabular}{|c|c|c|c|c|}
\hline \multirow{3}{*}{ Nitrogen doses $\left(\mathrm{kg} \mathrm{ha}^{-1}\right)$} & \multicolumn{4}{|c|}{ Root length of seedlings } \\
\hline & \multicolumn{2}{|c|}{ Alegrete-RS } & \multicolumn{2}{|c|}{ Pelotas-RS } \\
\hline & BRS Brau & BRS Cauê & BRS Brau & BRS Cauê \\
\hline 80 & $8.27 \mathrm{~A} \alpha$ & $8.78 \mathrm{~A} \alpha$ & $8.21 \mathrm{~B} \alpha$ & $9.06 \mathrm{~A} \alpha$ \\
\hline 120 & $8.11 \mathrm{~A} \alpha$ & $8.44 \mathrm{~A} \alpha$ & $5.53 \mathrm{~B} \beta$ & $9.21 \mathrm{~A} \alpha$ \\
\hline 160 & $7.29 \mathrm{~A} \alpha$ & $7.92 \mathrm{~A} \beta$ & $7.66 \mathrm{~B} \alpha$ & $8.96 \mathrm{~A} \alpha$ \\
\hline 200 & $7.09 \mathrm{~B} \alpha$ & $9.89 \mathrm{~A} \alpha$ & $7.62 \mathrm{~B} \alpha$ & $8.81 \mathrm{~A} \beta$ \\
\hline \multirow[t]{2}{*}{$\mathrm{CV}(\%)$} & \multicolumn{4}{|l|}{21.38} \\
\hline & \multicolumn{4}{|c|}{ Shoot dry matter of seedlings } \\
\hline \multirow[t]{2}{*}{ Nitrogen doses $\left(\mathrm{kg} \mathrm{ha}^{-1}\right)$} & \multicolumn{2}{|c|}{ Alegrete-RS } & \multicolumn{2}{|c|}{ Pelotas-RS } \\
\hline & BRS Brau & BRS Cauê & BRS Brau & BRS Cauê \\
\hline 80 & $0.0460 \mathrm{~A} \beta$ & $0.0525 \mathrm{~A} \alpha$ & $0.0560 \mathrm{~A} \alpha$ & $0.0521 \mathrm{~A} \alpha$ \\
\hline 120 & $0.0560 \mathrm{~A} \alpha$ & $0.0441 \mathrm{~B} \beta$ & $0.0591 \mathrm{~A} \alpha$ & $0.0555 \mathrm{~A} \alpha$ \\
\hline 160 & $0.0536 \mathrm{~B} \alpha$ & $0.0602 \mathrm{~A} \alpha$ & $0.0536 \mathrm{~A} \alpha$ & $0.0504 \mathrm{~A} \beta$ \\
\hline 200 & $0.0535 \mathrm{~A} \alpha$ & $0.0533 \mathrm{~A} \alpha$ & $0.0515 \mathrm{~A} \alpha$ & $0.0546 \mathrm{~A} \alpha$ \\
\hline $\mathrm{CV}(\%)$ & 16.41 & & & \\
\hline
\end{tabular}

Note. *Means followed by the same uppercase letter in the line (barley cultivars), and same Greek letter in the line(growing environments), do not statistically differ on Tukey test with $5 \%$ of probability.

The growing environment and the nitrogen fertilizing have large influence in the dry matter accumulation in seedlings. The higher magnitudes of this variable were obtained when the seeds where produced in Pelotas-RS, it can be related to the edaphoclimatic characteristics of the environment in which they were produced. 
The electric conductivity $(\mathrm{CH})$ for the seeds soaked during three hours, demonstrated that in the Alegrete-RS environment, the cultivar BRS Brau adjusted to a quadratic tendency with low efficiency point at the nitrogen dose of $138 \mathrm{~kg} \mathrm{ha}^{-1}$, resulting in $45 \mu \mathrm{S} \mathrm{cm}^{-1} \mathrm{~g}^{-1}$. The cultivar BRS Cauê demonstrated crescent linear tendency due to the increment in the nitrogen dose, and it was evidenced $49.02 \mu \mathrm{S} \mathrm{cm}^{-1} \mathrm{~g}^{-1}$. For Pelotas-RS, the cultivars adjusted to a linear tendency, where the BRS Brau showed crescent linear increase with the increment of the dose, achieving $41.78 \mu \mathrm{S} \mathrm{cm} \mathrm{cm}^{-1} \mathrm{~g}^{-1}$. The cultivar BRS Cauê presented a decreasing linear tendency when increasing the dose, showing $41.9 \mu \mathrm{S} \mathrm{cm}^{-1} \mathrm{~g}^{-1}$.

It was possible to observe that the environment Pelotas-RS presented lower values of the electric conductivity for both barley cultivars, in relation to the lower electrolytes lixiviation to the incubation environment (Table 4). As lower these values achieve, the better is the seeds physiologic quality, and these values were verified in the dose of $120 \mathrm{~kg} \mathrm{ha}^{-1}$ for the cultivar BRS Brau, and for the cultivar BRS Cauê, with the nitrogen dose of $160 \mathrm{~kg}$ $\mathrm{ha}^{-1}$ as the best management.

The reading of the electric conductivity of seeds soaked during 6 hours demonstrated that, at the environment Alegrete-RS, the cultivar BRS Brau adjusted to a quadratic tendency, with minimum efficiency point thru the dose of $135 \mathrm{~kg} \mathrm{ha}^{-1}$, obtaining $50.4 \mu \mathrm{S} \mathrm{cm}^{-1} \mathrm{~g}^{-1}$. The cultivar BRS Cauê adjusted to a crescent linear tendency, obtaining $56.12 \mu \mathrm{S} \mathrm{cm}^{-1} \mathrm{~g}^{-1}$. At the Pelotas-RS environment, the cultivar BRS Brau resulted in a decreasing linear tendency, due to the increase of the nitrogen dose, achieving $46.85 \mu \mathrm{S} \mathrm{cm}^{-1} \mathrm{~g}^{-1}$. The cultivar BRS Cauê demonstrated a quadratic tendency with minimum efficiency point with the dose of $152 \mathrm{~kg} \mathrm{ha}^{-1}$, with $45.4 \mu \mathrm{S}$ $\mathrm{cm}^{-1} \mathrm{~g}^{-1}$.

The cultivar BRS Brau had the lower electric conductivity value at Pelotas-RS, being verified thru the dose of $120 \mathrm{~kg} \mathrm{ha}^{-1}$ (Table 4). This same environment favored the cultivar BRS Cauê in the doses of 120, 160 and $200 \mathrm{~kg}$ $\mathrm{ha}^{-1}$ because of the low magnitudes obtained, highlighting the dose of $120 \mathrm{~kg} \mathrm{ha}^{-1}$ that obtained the value of 44.7 $\mu \mathrm{S} \mathrm{cm} \mathrm{cm}^{-1} \mathrm{~g}^{-1}$, respectively. For the electric conductivity $(\mathrm{CH})$ of the seeds soaked during 24 hours, it was demonstrated that in Alegrete-RS, both cultivars adjusted to a quadratic tendency. The cultivar BRS Brau had the minimum efficiency point in the nitrogen dose of $138 \mathrm{~kg} \mathrm{ha}^{-1}$, with $81.0 \mu \mathrm{S} \mathrm{cm}^{-1} \mathrm{~g}^{-1}$, the BRS Cauê resulted in $89,0 \mu \mathrm{S} \mathrm{cm}^{-1} \mathrm{~g}^{-1}$.

At the Pelotas-RS environment, the cultivar BRS Brau adjusted to a decreasing linear tendency, with $72.2 \mu \mathrm{S}$ $\mathrm{cm}^{-1} \mathrm{~g}^{-1}$, thru the maximum nitrogen dose. The cultivar BRS Cauê presented a quadratic tendency, with minimum efficiency at the nitrogen dose of $143 \mathrm{~kg} \mathrm{ha}^{-1}$, with $66.0 \mu \mathrm{S} \mathrm{cm}^{-1} \mathrm{~g}^{-1}$.

The seeds soaking time of 24 hours, evidenced that the lowest values of the electric conductivity were obtained in seeds originated from Pelotas-RS, for both cultivars the lowest values were obtained at the nitrogen dose of $120 \mathrm{~kg} \mathrm{ha}^{-1}$. The reading of the electric conductivity proportionate a fast and objective estimate of the seed vigor, because it is related to the amount of lixiviated ions in the solution in which is associated the membrane integrity (Costa et al., 2010).

When analyzing the results (Table 4), it was evident that the Pelotas-RS environment, at the nitrogen dose of 120 $\mathrm{kg} \mathrm{ha}^{-1}$, presented lower values of electric conductivity, as much for the cultivar BRS Brau as for the BRS Cauê, independent of the readings realized. This result represents better vigor, since the obtaining of low values is related to the seeds vigor, and the cells' membrane system integrity (Peske et al., 2012). The seed vigor is inversely proportional to the electric conductivity reading (Vieira et al., 2009). At the Alegrete-RS environment, it was verified more elevated values of the conductivity readings, what can be a low vigor indicative. The increase in the conductivity shows that a more accelerated deterioration process of the membrane and cell wall occurred (Szareski et al., 2016). Nitrogen doses above $160 \mathrm{~kg} \mathrm{ha}^{-1}$ proportionate increment in the electric conductivity for both growing environments.

The isoenzyme esterase expression (EST) demonstrated distinct form at different nitrogen doses for each barley cultivar. At Pelotas-RS, there was a reduction in the intensity and in the number of bands due to the increment in the nitrogen dose for both barley cultivars. The higher intensities were visualized with the BRS Brau at the nitrogen dose of $80 \mathrm{~kg} \mathrm{ha}^{-1}$ and the BRS Cauê in the dose of $120 \mathrm{~kg} \mathrm{~h}^{-1}$, resulting in theoretical molecular masses of 0,68 mol.w, respectively (Figure 1a). The increase in the dose could have caused damages in the seed membrane, what is associated o the lipids peroxidation, which can contribute to the reduction of the seeds germination percentage (Valente et al., 2011).

At the Alegrete-RS environment, the increase in the nitrogen dose caused a surge in the intensity and in the number of bands. These effects were observed in the cultivars at the nitrogen dose of $200 \mathrm{~kg} \mathrm{ha}^{-1}$. This isoenzime is related to the lipids catabolism, carbon source for new molecules synthesis in seedlings (Deuner et al., 2016). 
The expression of the acid phosphatase isoenzyme (ACP) in barley seeds exposed to different nitrogen doses, for Pelotas-RS, in the cultivar BRS Brau, detected ACP bands in all traits, although in the dose of $200 \mathrm{~kg} \mathrm{ha}^{-1}$, there was the highest expression. For the cultivar BRS Cauê, as the nitrogen doses increased there was lower band intensity. At the Alegrete-RS environment, the cultivar BRS Brau demonstrated that the expression was gradually decreasing when enhancing the nitrogen doses, with mass of $0.25 \mathrm{~mol} \mathrm{w}$ in the dose of $200 \mathrm{~kg} \mathrm{ha}^{-1}$ (Figure 1b).

For the BRS Cauê, there was bands presence with very low intensity, presenting a theoretical mass of 0.1 mol.w. The enzyme activity is inversely proportional to the phosphorus presence in the plant, because when the intensity of the enzyme expression increases the phosphorus amount decreases (Malane et al., 2007).

The glutamate-oxaloacetate isoenzyme (GOT) expressed in a similar way according to the levels of nitrogen fertilizing, in the Pelotas-RS environment, not being observed variation on the intensity of seed bands, with all traits expressing more than one band. At the Alegrete-RS environment, the cultivar BRS Cauê, at the dose of 200 $\mathrm{kg} \mathrm{ha}^{-1}$. At the Alegrete-RS environment, the cultivar BRS Cauê at the nitrogen dose of $200 \mathrm{~kg} \mathrm{ha}^{-1}$ observed a third band, showing a mass of $0.98 \mathrm{~mol} \mathrm{w}$ (Figure 1c). The answer of the intensification of band numbers, due to the nitrogen doses increase, is because of the rise in the metabolic activity with deterioration process of seeds membranes.

a)

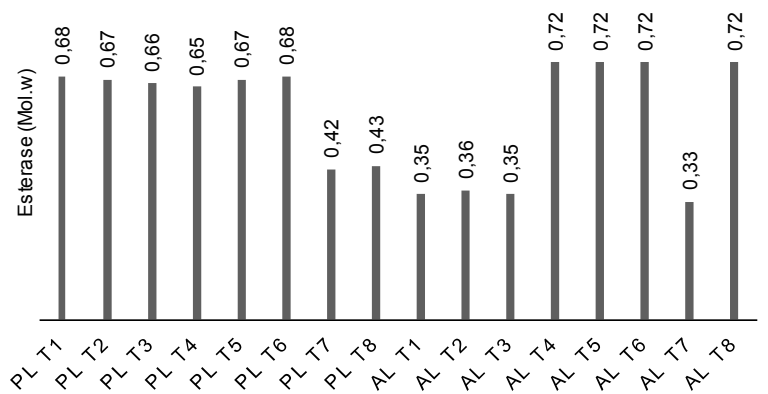

c)

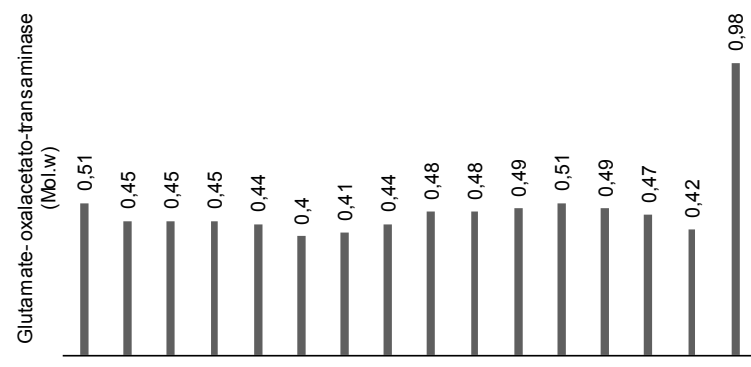

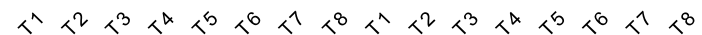

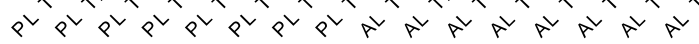

b)

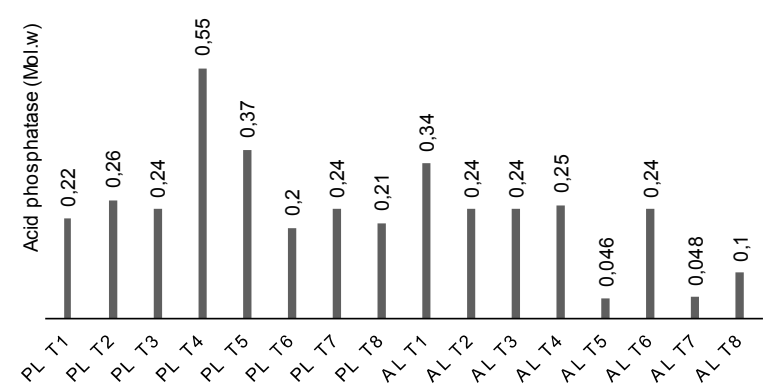

d)

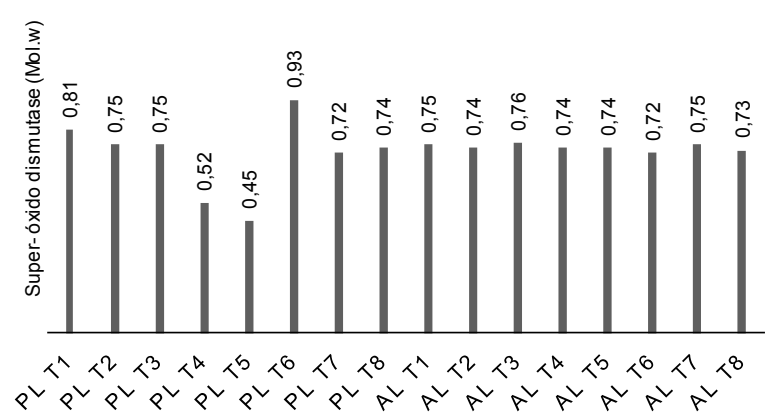

Figure 1. Profile of isoenzymatic expressions (A: Esterase, B: Acid phosphatase, C: Glutamate-oxaloacetate transaminase, D: Super-oxide dismutase) in Barley seedlings of the cultivar BRS Brau (AL T1 $=80 \mathrm{~kg} \mathrm{ha}^{-1}, \mathrm{AL}$ $\mathrm{T} 2=120 \mathrm{~kg} \mathrm{ha}^{-1}, \mathrm{AL} \mathrm{T} 3=160 \mathrm{~kg} \mathrm{ha}^{-1}$ and AL T4 = $200 \mathrm{~kg} \mathrm{ha}^{-1}$ ) and BRS Cauê (AL T5 = $80 \mathrm{~kg} \mathrm{ha}{ }^{-1}, \mathrm{AL} \mathrm{T} 6=$ $120 \mathrm{~kg} \mathrm{ha}^{-1}, \mathrm{AL} \mathrm{T} 7=160 \mathrm{~kg} \mathrm{ha}^{-1}$ and AL T8 $\left.=200 \mathrm{~kg} \mathrm{ha}^{-1}\right)$. BRS Brau (PL T1 = $80 \mathrm{~kg} \mathrm{ha}^{-1}, \mathrm{PL} \mathrm{T} 2=120 \mathrm{~kg} \mathrm{ha}{ }^{-1}$, PL T3 $=160 \mathrm{~kg} \mathrm{ha}^{-1}$ and PL T4 $\left.=200 \mathrm{~kg} \mathrm{ha}^{-1}\right)$ and BRS Cauê $\left(\right.$ PL T5 = $80 \mathrm{~kg} \mathrm{ha}^{-1}$, PL T6 $=120 \mathrm{~kg} \mathrm{ha}^{-1}$, PL T7 = $160 \mathrm{~kg} \mathrm{ha}^{-1}$ and PL T8 $=200 \mathrm{~kg} \mathrm{ha}^{-1}$ )

The isoenzyme superoxide dismulase (SOD) expression demonstrates that at the Pelotas-RS, for the cultivar BRS Brau, there was a lower intensity in the bands number with the nitrogen dose increase. This enzyme has the function of converting the superoxide free radicals $\left(\mathrm{O}_{2}^{-}\right)$, produced in two different cell parts, to molecular oxygen and $\mathrm{H}_{2} \mathrm{O}_{2}$. 
The BRS Cauê presented distinct format by different nitrogen doses, presenting higher molecular mass values, at the $210 \mathrm{~kg} \mathrm{ha}^{-1}$ nitrogen dose (Figure 1d). At the Alegrete-RS environment, the SOD izoenzyme presented similar band expression in seedlings, in relation to nitrogen doses. This enzyme is important in the plants defense in response to pathogens attack, thru the plants cells detoxification (Shen et al., 2010).

The variables response to the interactions demonstrate that the physiologic compounds can be influenced by nitrogen doses, barley cultivars and the environment in which they are cultivated. According to Toledo et al. (Valente et al., 2011), the physiologic quality of seeds can be altered in relation to the characteristics imposed by the environment, affecting the plant and seeds produced.

As stated by Biazus (Szareski et al., 2016), the optimal conditions for the growing period must dovetail between $10{ }^{\circ} \mathrm{C}$ to $24^{\circ} \mathrm{C}$, for the maximum carbon accumulation. The barley plant has a $\mathrm{C}_{3}$ metabolism, and in elevated air temperatures and excessive radiation conditions, it can occur photorespiration and incorporation of biphosphate-ribolose rather than carbon, what can decrease the efficiency of photosynthetic process (Rodrigues et al., 2015). By occurring reduction of the photosynthetic process, the biomass production could be prejudiced, as well the conversion and deposition of photo-assimilates in the endosperm cells, and thus damaging the embryo structure and development (Heinemann et al., 2006).

Other parameter that presented lower value for Alegrete-RS environment was the air relative humidity, which oscillated between 61 to $68 \%$. According to Minella (Valente et al., 2011), the region with high luminosity, low air relative humidity and mild air temperatures during the seeds formation, filling and maturation phases, characterizes as favorable environments for higher quality. Peske et al. (2012) highlights that the environment in which the seeds are produced and the offered conditions have large influence in the germinating potential, where unfavorable environments resulted in low quality seeds.

A similar result was found by Bono et al. (2008), where by elevating nitrogen doses above $120 \mathrm{~kg} \mathrm{ha}^{-1}$ he obtained reduction of normal seedlings and, consequently, reduced seeds vigor.

The first germination counting is considered a non-standardized vigor test, largely used to express and differentiate vigor levels among seeds (Szareski et al., 2018). The expression of the potential of a cultivar depends on the growing environment, the cultivars $\times$ environments interaction and adaptations to environmental variations (Wohlenberg et al., 2013).

The vigor evaluation by the accelerated aging test the test realization is based in the fact that the seeds deterioration rate is linearly increased, because of the exposition to high levels of temperature and air relative humidity, being these factors considered the main causes of seeds deterioration (Binotti et al., 2008). According to Marcos Filho, more vigorous seeds present elevated germination, after being submitted to accelerated aging, while the low vigor ones reduce its viability. Abrantes et al. (2010) obtained significant difference with the increase in nitrogen dose, causing a decrease in the germination percentage.

In relation to field emergency, it is realized in order to verify the seeds physiological potential at adverse conditions, being favorable or not (Abrantes et al., 2010). The Pelotas environment demonstrated favorable to the vigor evaluation by field emergency, where both cultivars performed crescent linear due to the increase of the nitrogen dose. It can occur because nitrogen has a relation to the plant metabolism, by increasing the protein, aminoacid and other compounds content that are important to the seed, being favorable to the formation of a better-nourished plant, and that express its potential.

As stated by Marini et al. (2009), when the nitrogen application is not enough and do not furnish the plant necessity, occurs a blocking in the cytokine, a hormone responsible by the plants growth, and can reduce the seeds production. Smiderle et al. (2011), sustain that the nitrogen favors the protein content and the enzymatic activities in seeds, improving the field emergence and plant aspects.

The variable seedling root length similar results were found by Piazzetta et al. (2014), which observed that the treats that received lower nitrogen doses tended to demonstrate higher radicular growth.

Dry matter of seedlings these results are concurrent with Souza et al. (2013), which found higher dry matter production in the nitrogen dose of $148 \mathrm{~kg} \mathrm{ha}^{-1}$. Viana and Kiehk (2010), working with different nitrogen and potassium doses, verified higher accumulation of dry mass thru the nitrogen dose of $225 \mathrm{~kg} \mathrm{ha}^{-1}$.

As well as for the growing environment, the nitrogen doses increase above the recommended, allowed higher shoot dry matter in the seedlings. Schoroder et al. (2007) affirms that this nutrient assists in the vegetative development of plants, acting mostly in the initiation and foliar expansion, in the final size of leaves and stem height. 
The electric conductivity these results are in concordance with the ones obtained by Sangoi et al. (2010), where the increase in the electric conductivity is due to higher nitrogen doses between 100 and $200 \mathrm{~kg} \mathrm{ha}^{-1}$. Prando et al (2012) defined a crescent behavior of the electric conductivity as the nitrogen dose increased, affirming that this fact can occur due the superior accumulation of nutrients present in the culture. By the analysis of four enzymatic systems, it was possible to visualize that there was variation in the isoenzymatic expression intensity, as the increasing in the nitrogen doses, due to this variation each system was separately analyzed.

This isoenzime according to Aumonde et al. (2013), the number and intensity of esterase bands, is related to the seeds quality. In this manner, higher values results in higher viability demonstrating that the isoenzymatic system is linked to the seeds deterioration process (Coutinho, 2007).

The expression of the acid phosphatase isoenzyme according to Tunes et al. (2010), the acid phosphatase participates of the reactions of esters hydrolysis, and can provoke lipids peroxidation, if operate on phospholipids of seeds membrane. According to Lemes et al. (2006) glutamate-oxaloacetate isoenzymethe increase in this enzyme expression is inversely proportional to the seeds quality, being responsible for the amino acids oxidation. Chauhan et al. (1985) state larger band intensity to the isoenzyme glutamate-oxaloacetate-transaminase, after seeds passed thru aging process.

Similar answer was obtained by Muniz et al. (2007) with corn, where they observed an increase in the isoenzyme activity with the increase on the concentration of the Cyperus rotundus extract, indicating a quality reduction. The GOT is related to the nitrogen metabolism, by participating in transamination reactions during the amino acids' nitrogen elimination. In addition, it supplies energy for the Krebs cycle or reduction of the $\alpha$-ketoglutarate for new amino acids synthesis (Wrege et al., 2011).

In general, the effects of the increment in nitrogen doses, besides the recommended, demonstrated positive effect at the physiologic quality of seeds and in the isoenzymes expression. This result was verified ant the Alegrete-RS environment, proved by the germination test, first counting of germination, accelerated aging and root length. This result is due, partly, to the environment edaphoclimatic characteristics where the seeds where produced, mostly to the organic matter ratio that was low, requiring higher fertilizing.

For the Pelotas-RS environment, the seeds showed more vigor, verified thru the field emergency and electric conductivity tests. The soil structure, constituted of higher organic matter contributed for seeds with high expressivity. In this manner, the nitrogen doses proportionated higher protein content, consequently higher reserve content, resulting better membrane quality.

\section{Conclusions}

The growing environment promotes differences in the barley seeds physiologic quality. The nitrogen fertilizing, at dose of $120 \mathrm{~kg} \mathrm{ha}^{-1}$, results in superiority in the physiologic quality of seeds. The cultivar BRS Cauê in both environments presented higher vigor. The nitrogen fertilizing alters the isoenzymatic expression of barley seedlings, creating variation in the bands intensity, at different nitrogen doses. This study secured the importance of the nitrogen fertilizing on the physiologic and biochemical quality of brewing barley seeds produced in the state of Rio Grande do Sul, main producer of Brazil.

\section{Acknowledgements}

To Coordenação de Aperfeiçoamento de Pessoal de Nível Superior (CAPES) and the Conselho Nacional de Desenvolvimento Científico e Tecnológico (CNPq) for the scholarship granted.

\section{References}

Abrantes, F. L., Kulczynski, S. M., Soratto, R. P., \& Barbosa, M. M. (2010). Nitrogen top-dressing and the physiological and sanitary quality of proso millet (Panicum miliaceum L.) SEEDS. Revista Brasileira de Sementes, 32, 106-115. https://doi.org/10.1590/S0101-31222010000300012

Aumonde, T. Z., Pedó, T., Martinazzo, E. G., Borella, J., \& Villela, F. A. (2013). Isoenzymatic expression of red rice seeds and seedlings under the action of extracts of two Araceae species. Revista Ciências Agrárias, 56, 283-286. https://doi.org/10.4322/rca.2013.040

Binotti, F. F. S., Haga, K. I., Cardoso, E. D., Alves, C. Z., Eustáquio, M., \& Arf, O. (2008). Relationships of acellerated aging time with bulk conductivity test and with physiological seed quality in common bean. Revista Acta Scientiarum, Agronomy, 30, 247-254.

Bono. J. A. M., Rodrigues, A. P. C., Mauad, M., Albuquerque, J. C., Yamamoto, C. R., Chermouth, K. S., \& Freitas, M. E. (2008). Application of fertilizers nitrogened in the quality physiologic of maize seeds. Revista Agrarian, 1, 91-102. 
Boyles, S. L., Anderson, V. L., \& Koch, K. B. (2018). Feeding barley to cattle. Retrieved from https://agnr.osu.edu/sites/agnr/files/imce/pdfs/Beef/FeedingBarleyToCattle.pdf

Caierão, E., Cunha, G. R., \& Pires, J. L. F. (2009). Cevada. In J. E. B. A. Monteiro (Ed.), Agrometeorology of crops: the meteorological factor in agricultural production (pp. 169-181). Brasília: INMET.

Chauhan, K. P. S., Gopinathan, M. C., \& Babu, C. R. (1985). Electrophoretic variations of proteins and enzymes in relation to seed quality. Seed Science and Technology, 13, 629- 641.

Costa, A. R., Faroni, L. R. D., Alencar, E. R., Carvalho, M. C. S., \& Ferreira, L. G. (2010). Quality of corn grain stored in silo bags. Revista Ciência Agronômica, 41, 200-207. https://doi.org/10.1590/S1806-669020100 00200005

Coutinho, W. M., Silva-Mann, R., Vieira, M. G. G. C., \& Machado, C. F. (2007). Health and physiological quality of maize seeds submitted to thermotherapy and physiological preconditioning. Fitopatologia Brasileira, 32, 458-464. https://doi.org/10.1590/S0100-41582007000600002

De Mori, C., \& Minella, E. (2012). Economic and conjunctural aspects of barley culture (p. 28). Embrapa Trigo. Passo Fundo.

Deuner, C., Almeida, A. S., Borges, C. T., Jauer, A., Troyjack, C., \& Meneghell, G. H. (2016). Expression of isoenximes in kidney bean seedlings of calves treated with biativador. Tecnologia \& Ciência Agropecuária, 10, 69-73.

Deuner, C., Almeida, A. S., Borges, C. T., Jauer, A., Troyjack, C., \& Meneghell, G. H. (2016). Expression of isoenximes in kidney bean seedlings of calves treated with biativador. Tecnologia \& Ciência Agropecuária, 10, 69-73.

Embrapa (Empresa Brasileira de Pesquisa Agropecuária). (2013). Brazilian system ofsoilclassification (3rd ed., p. 353). Rio de Janeiro: Embrapa Solos.

Embrapa (Empresa Brasileira de Pesquisa Agropecuária). (2005). Sistema Brasileiro de análise do solo (p. 374). Brasília.

FAOSTAT. (2018). Statistical Database. Food Agriculture Organization of the United Nations. Retrieved from http://www.fao.org/statistics/databases/en

Ferreira, C. (2015). Cultivars of barley sown in simple and matched spacings combined with doses of fertilizer and sowing density (p. 73, Thesis, Universidade Estadual de Ponta Grossa, Brazil).

Heinemann A. B., Stone L. F., Didonet, A. D., Trindade, M. D. A. G., Soares, B. B., Moreira, J. A. A., \& Cánovas, A. D. (2006). Solar radiation use efficiency on the wheat grain yield as a function of nitrogen fertilizer. Revista Brasileira de Engenharia Agricola e Agricola e Ambiental, 10, 352-356. https://doi.org/ $10.1590 /$ S1415-43662006000200015

Jianhua, Z., \& Mcdonald, M. B. (1996). The saturated salt accelerated aging test for small seed crops. Seed Science and Technology, 25, 123-131.

Malone, G., Zimmer, P, D., Meneghello, G, E., Castro, M, A, S., \& Peske, S. T. (2007). Isoenzimaticdiferential expression among rice seed germination process in great depth sowing. Revista Brasileira de Sementes, 29, 61-67. https://doi.org/10.1590/S0101-31222007000100009

MAPA (Ministério da Agricultura, Pecuária e Abastecimento). (1996). Portaria $n^{o} 691$ de 22 de novembro de 1996. Official Diary of the Union, 25 Novembro, Seção I.

MARA (Ministério da Agricultura e da Reforma Agrária). (2009). Rules for seed analysis (p. 399). Brasília: Secretariat of Agricultural Defense. Brasília: MAPA/ACS.

Marini, P., Lowe, T. R., Moraes, C. L., Moraes, D. M., \& Lopes, N. F. (2009). Physiological quality of seeds and growth of lettuce (Lactua sativa L.) seedlings submitted to nitrogen. Revista Brasileira de Sementes, 31, 222-227. https://doi.org/10.1590/S0101-31222009000100025

Meneghin M. F. S., Ramos, M. L. G., Oliveira, A. S., Ribeiro Junior, W. Q., \& Amabile, R. F. (2008). Soilnitrogenavailability for wheat in a cerradoredlatosol. Revista Brasileira de Ciência do Solo, 32, 1941-1948. https://doi.org/10.1590/S0100-06832008000500015

Muniz, F. R., Cardoso, M. G., Vonpinho, E. V. R., \& Vilela, M. (2007). Physiological quality of corn, bean, soybean and lettuce seeds in the presence of sedge extract. Revista Brasileira de Sementes, 29, 195-204. https://doi.org/10.1590/S0101-31222007000200026 
Nakagawa, J. (1999). Stability tests based on seedling performance. In F. C. Krzyzanowski, R. D. Vieira, \& J. B. Françaneto (Eds.), Seed vigor: Conceptsand tests (2nd ed., pp. 1-21). Londrina: ABRATES.

Peske, S. T., Villela, F. A., \& Meneguello, G. E. (2012). Sementes: Fundamentos Cientificos e Tecnológicos (3rd ed., p. 573). Pelotas.

Piazzetta, H. V. L., Moraes, A., Ribeiro, T. M. D., Sandini, I. E., Lustosa, S. B. C., \& Pelissari, A. (2014). Grazing and nitrogen on the growth of roots in the mixture of oat and ryegrass. Revista Ciências Agrárias, 35, 2748-2768.

Prando, A. M., Zucareli, C., Fronza, V., Oliveira, E. A. P., \& Panoff, B. (2012). Forms of urea and nitrogen levels in topdressing on the physiological quality of wheat seeds. Revista Brasileira de Sementes, 34, 272-279. https://doi.org/10.1590/S0101-31222012000200012

Raij, B. V., \& Quaggio, A. J. (1983). Métodos de análise de solo para fins de fertilidade (p. 31). Campinas: Instituto Agronômico.

Rodrigues, M. A., Morais, J. S., \& Castro, J. P. M. (2015). Jornadas de Lúpulo e cerveja (p. 35). Bragança. Livro de atas, Instituto Politécnico de Bragança.

Sangoi, L., Almeida, M. L., Pucci, A. L. R., Strieder, M., Zanim, C. G., Silva, L. C., \& Vieira, R. J. (2008). Early nitrogen side-dress application does not increase wheat grain yieldat the aluminum presence. Ciência Rural, 38, 912-920. https://doi.org/10.1590/S0103-84782008000400002

Scandalios, J. G. (1969). Genetic control of multiple molecular forms of enzymes in plants: A review. Biochemical Genetics, 3, 37-39. https://doi.org/10.1007/BF00485973

Schröder, J. J., Uenk, G., \& Hilhorst, G. J. (2007). Long-term nitrogen fertilizer replacement value of cattle manures applied to cut grassland. Plant and Soil, 299, 83-89. https://doi.org/10.1007/s11104-007-9365-7

Shen, X., Zhou, Y., Duan, L., Li, Z., Eneji, A. E., \& Li, J, (2010). Silicon effects on photosynthesis and antioxidant parameters of soybean seedlings under drought and ultraviolet-B radiation. Journal of Plant Physiology, 167, 1248-252. https://doi.org/10.1016/j.jplph.2010.04.011

Silva, E. C., Buzetti, S., Guimarães, G. L., Lazarini, E., \& Sá, E. (2005). Rates and timing of nitrogen application in corn under no-tillage on a red latosol. Revista Brasileira de Ciência do Solo, 29, 353-362. https://doi.org/10.1590/S0100-06832005000300005

Smiderle, O. J., Chang, M. T., Ferreira, G. B., \& Cordeiro, A. C. C. (2011). Quality of BRS jaçanã rice seeds in response to application of nitrogen. Revista Acadêmica Ciências Agrárias e Ambientais, 9, 79-86. https://doi.org/10.7213/cienciaanimal.v9i1.11102

SBCS (Sociedade Brasileira de Ciência do Solo). (2016). Manual of Liming and Fertilization for the states of Rio Grande do Sul and Santa Catarina (11th ed., p. 376). SBCS/South Regional Nucleus; Soil Fertility Commission-RS/SC.

Souza, S. R., Fernandes, M., \& Nitrogênio, S. (2006). In M. S. Fernandes (Ed.), Nutrição mineral de plantas (pp. 215-252). Viçosa, Sociedade Brasileira de Ciência do Solo.

Szareski, V. J., Carvalho, I. R., Demari, G. H., Pelissari, G., Pelegrin, A. J., Barbosa, M. H., ... Aumonde, T. Z. (2018). Path analysis applied to agronomic traits of contrasting growth habit soybeans. Australian Journal of Crop Science, 12, 531-538. https://doi.org/10.21475/ajcs.18.12.04.pne608

Szareski, V. J., Carvalho, I. R., Demari, G. H., Souza, V. Q., Rosa, T. C., Villela, F. A.,... Aumonde, T. Z. (2018). Multivariate index of soybean seed vigor: A new biometric approach applied to the effects of genotypes and environments. Journal of Seed Science, 40(4), 396-406. https://doi.org/10.1590/2317-1545v40n4198333

Szareski, V. J., Carvalho, I. R., Kehl, K., Levien, A. M., Nardino, M., Dellagostin, S. M., ... Aumonde, T. Z. (2018). Evaluation of the adaptability and stability of wheat genotypes using a phenotypic index of seed vigor. Pesquisa Agropecuária Brasileira, 53(6), 727-735. https://doi.org/10.1590/s0100-204x20180006 00009

Szareski, V. J., Carvalho, I. R., Kehl, K., Levien, A. M., Rosa, T. C., Barbosa, M. H., ... Aumonde, T. Z. (2018). Phenotypic and predicted genetic approaches for genotype ranking of wheat seed yield in Brazil. Genetics and Molecular Research, 17, 1-13. https://doi.org/10.4238/gmr18026 
Szareski, V. J., Carvalho, I. R., Nardino, M., Demari, G. H., Pelegrin, A. J., Ferrari, M., ... Aumonde, T. Z. (2016). Seeding rate and physiological quality of dual purpose wheat seeds. African Journal of Agricultural Research, 11, 4367-4374. https://doi.org/10.5897/AJAR2016.11578

Szareski, V. J., Carvalho, I. R., Nardino, M., Demari, G., Bahry, C. A., ... Aumonde, T. Z. (2016). Phenotype stability of soybean genotypes for characters related to the physiological quality of seeds produced under different environmentall conditions. Australian Journal of Basic and Applied Sciences, 10, 279-289.

Szareski, V. J., Carvalho, I. R., Rosa, T. C., Dellagostin, S. M., Pelegrin, A. J., Barbosa, M. H., ... Pegoraro, C. (2018). Oryza wild species: An alternative for rice breeding under abiotic stress conditions. American Journal of Plant Sciences, 9, 1093-1104. https://doi.org/10.4236/ajps.2018.96083

Szareski, V. J., Zanatta, E., Koch, F., Aisenberg, G. R., Demari, G. H., Kehl, K., ... Aumonde, T. Z. (2016). Pre-harvest desiccation and seed production in soybean crops. International Journal of Current Research, 8 , 41534-41537.

Tunes, L. M., Pedroso, D. C., Meneghello, G. E., Castro, M. A. S., Barros, A. C. D. A., Badinelli, P. G., \& Muniz, M. F. B. (2010). Enzymatic profile in barley seeds in response to different saline concentrations. Revista Interciência, 35, 369-373.

Valente, B. S., Xavier, E. G., Moraes, P. O., Manzke, N. E., \& Roll, V. F. B. (2011). Efficiency of SISCODE and passive aeration for treating residues of animal production in Capão do Leão City - Rio Grande do Sul State. Revista Engenharia Sanitária e Ambiental, 16, 231-236. https://doi.org/10.1590/S1413-41522011000 300005

Viana, E. M., \& Kiehl, J. C. (2010). Nitrogen and potassium doses in wheat growth. Bragantia, 69, 975-982. https://oi.org/10.1590/S0006-87052010000400024

Vieira, E. S. N., Von Pinho, E. V. R., Carvalho, M. G. G., \& Silva, P. A. (2009). Characterization of soybean cultivars by morphological descriptors and biochemical markers of proteins and isoenzymes. Revista Brasileira de Sementes, 31, 86-94. https://doi.org/10.1590/S0101-31222009000100010

Vieira, R. D., \& Krzyzanowski, F. C. (1999). Teste De Condutividade Elétrica. In F. C. Krzyzanowski, R. D. Vieira, J. B. França Neto (Eds.), Seed vigor: Conceptsandtests (Cap. 4, pp. 1-26). Brasília: ABRATES.

Wohlenberg, M. D., Olegário, M., Sberse, V., Mazurkievicz, Silva, A. J., \& Silva, J. A. G. (2013). The genetic potential of white oat strains searching for the release of cultivars adjusted to the northwest region of Rio Grande do Sul. Hall of Knowledge.

Wrege, M. S., Steinmetz, S., Junior Reisser, C., \& Almeida, I. R. (2011). Climate Atlas of Southern Brazil: Statesof Paraná, Santa Catarina and Rio Grande do Sul (p. 211). Pelotas: Embrapa temperateclimate; Colombo: Embrapa Forests.

\section{Copyrights}

Copyright for this article is retained by the author(s), with first publication rights granted to the journal.

This is an open-access article distributed under the terms and conditions of the Creative Commons Attribution license (http://creativecommons.org/licenses/by/4.0/). 